\title{
THE FEEDING VALUE OF CURED PARKIA FILICOIDEA WELW. LEAVES WITH CASSAVA PEELS TO THE GOAT
}

\author{
A. A. Adeloye, B. Awosanya, K. Joseph \& S. Olawoye \\ Department of Animal Production, University of Ilorin, PMB 1515, Ilorin, Nigeria
}

(Received 15 April 1992; revised version received 2 January 1993; accepted 11 January 1993)

\begin{abstract}
The influence of supplementary inclusion of Parkia filicoidea Welw. hay in a cassva-peel diet for goats was evaluated by a digestibility study. Eighteen Sokoto red goats, $6.0-7.5 \mathrm{~kg}$, were involved. There were six diets comprising unsupplemented cassava peels; 25, 50 and $75 \%$ replacements with Parkia hay; whole Parkia hay; and the control. The control diet was of $60 \%$ Andropogon gayanus and $40 \%$ yellow maize and soybean meal mixed in a 1.5:1 ratio.

Dry matter (DM) intake (g/head per day) was better $(P<0.05)$ with whole Parkia hay $(153 \pm 34.5)$ than with the cassava peels (137 $\pm 12 \cdot 9)$. Nevertheless, DM intakes were far better (>200 g/head per day) on the supplemented diets. Acceptabilities were enhanced at (cassava peel/Parkia hay) 25/75 and 50/50 mixtures.

DM digestibilities were higher on unsupplemented cassava peels, 25 and $50 \%$ replacements than with Parkia hay. Nutrient digestibilities were higher $(P<0.05)$ with the $50 \%$ replacement diet, except for crude fibre and total ash.

The availability of the cassava peel and Parkia hay at little or no cost and the digestibility of the 50/50 combination as against that of the conventional (control) diet would make the 50/50 combination of the plant products an acceptable dry-season feed and a suitably cheap feed in subsistence goat-production.
\end{abstract}

Key words: Feeding value, Parkia filicoidea, legume forage, cassava peels, crop waste, goat.

\section{INTRODUCTION}

Cassava peels have been shown to constitute 10-15\% by weight of the whole tuber (Oyenuga, 1968). This energy-rich by-product is available at no extra cost and has been included in ruminant diets (Ifut, 1983) but its low crude-protein and the hydrocyanic acid content of the peels call for a supplementary source of nitrogen. It has been reported (Minson \& Milford, 1967) that protein supplementation of an energy-rich material, when its crude protein is less than $7 \%$, increases food intake and animal performance.

In ruminant nutrition, the quality of protein is of little importance as the dietary protein is converted to microbial protein in the rumen before it is utilized by the animal. Therefore, the supplementation of cassava peels with nitrogen from the foliage of tree legumes is of real practical relevance.

The African locust bean (Parkia filicoidea Welw.) plant is a medium-sized perennial tree that produces a readily available and continuous supply of numerous green leaflets and fruited pods. It could therefore contain appreciable amounts of crude protein, being a legume. Work has been done on the beans (fruits) of $P$. filicoidea (Fetuga et al., 1974; Balogun \& Odutuga, 1982; Balogun \& Fetuga, 1986) but information is non-existent on the efficacy of the leaves as feed for livestock. The goat is remarkably adapted to digesting coarse plant-materials. The ability of this ruminant species in converting some lignocellulosic waste materials to meat has been documented (Adeloye, 1992). This report presents the feeding value of graded levels of cured $P$. filicoidea Welw. leaves with mixed varieties of dried cassava peels in the diet of the goat.

\section{METHODS}

The cassava peels were derived from a mixture of Manihot esculenta and Manihot utilissima as obtained from a 'gari' processing centre at Tanke Village in Ilorin, Nigeria. The peels were sun-dried on concrete slabs for 10-15 days depending on the intensity of the sun. The peels were afterwards packed in jute bags and stored.

Fresh Parkia filicoidea branchlets and leaves were harvested in the University of Ilorin. The branchlets were tied into bunches and each bunch was made to stand on the stubbles, thereby lifting up the leaves to air-dry in the shade for two weeks. The leaves and midribs were later beaten out, separated and bagged in jute sacks kept on wooden planks. 
Eighteen Sokoto-red grower goats weighing 6-7.5 $\mathrm{kg}$ were dewormed and randomly allotted to six groups, each group consisting of three goats. There were six diets made up of a control, the Parkia hay alone, the cassava peels alone and three others of varying Parkia hay/cassava peels combinations. Each group of goats was placed on each of the diets and regarded as a treatment. Thus, there were six treatments (Table 1).

Each goat was housed in a metabolism crate with facilities for the collection of urine and faeces. The feeds were ground to provide an all-concentrate form of ration (Adeloye, 1992). Each animal was fed at 5\% of body weight and refusals were recovered to estimate intakes. Fresh water was provided daily ad lib. The ani-

Table 1. Composition of the diets (\% of ration)

\begin{tabular}{|c|c|c|c|c|c|c|}
\hline Diets & $\begin{array}{l}\text { Cassava } \\
\text { peels }\end{array}$ & $\begin{array}{c}\text { Parkia } \\
\text { hay }\end{array}$ & Dry matter & $\begin{array}{l}\text { Crude } \\
\text { protein }\end{array}$ & $\begin{array}{l}\text { Crude } \\
\text { fibre }\end{array}$ & $\begin{array}{c}\text { Organic } \\
\text { matter }\end{array}$ \\
\hline 1 & 100 & - & $88 \cdot 58$ & $4 \cdot 05$ & $35 \cdot 57$ & $81 \cdot 9$ \\
\hline 2 & 75 & 25 & $85 \cdot 19$ & $6 \cdot 56$ & 31.68 & 84.69 \\
\hline 3 & 50 & 50 & 96.54 & $7 \cdot 50$ & $27 \cdot 80$ & $87 \cdot 48$ \\
\hline 4 & 25 & 75 & $95 \cdot 95$ & $9 \cdot 38$ & 23.90 & $90 \cdot 27$ \\
\hline 5 & - & 100 & $85 \cdot 64$ & $10 \cdot 94$ & $20 \cdot 01$ & 93.06 \\
\hline 6 & Control $^{a}$ & & $94 \cdot 80$ & $14 \cdot 69$ & $23 \cdot 60$ & $89 \cdot 9$ \\
\hline
\end{tabular}

${ }^{a}$ Control ration:

$\left.\begin{array}{lc} & \begin{array}{c}\% \text { of ration } \\ \text { Andropogon gayanus }\end{array} \\ \begin{array}{l}\text { Yellow maize } 60 \% \\ \text { Soybean meal } 40 \%\end{array}\end{array}\right] \quad \frac{40}{\underline{100}}$

mals were allowed 15 days to adjust to the cages and the experimental diets followed by a five-day collection period.

The total faeces were collected daily for each goat, $10 \%$ of which was oven-dried at $105^{\circ} \mathrm{C}$ to constant weight to eliminate moisture. The faecal dry matter was weighed and bulked for each animal.

Chemical analyses of the feeds and faeces followed standard AOAC (1980) procedure. The dry matter was determined by oven-drying a known weight of the sample in a forced-draught oven at $105^{\circ} \mathrm{C}$ to constant weight. Crude protein $(N \times 6.25)$ was determined by a micro-Kjeldahl method and crude fibre by the trichloroacetic acid method. Ether extract was estimated by the soxhlet extraction method. Ash was determined by ignition in a muffle furnace at $600^{\circ} \mathrm{C}$ for $3 \mathrm{~h}$; nitrogenfree extract was estimated by difference. The results were subjected to analysis of variance (Steel \& Torrie, 1980) and means tested (Duncan, 1955).

\section{RESULTS AND DISCUSSION}

The trend of dry matter intakes showed that the acceptabilities of cassava peels and Parkia hay were enhanced at mixtures of (cassava peel/Parkia hay) 25/75 and $50 / 50$. Beyond $50 \%$ inclusion of Parkia hay there was a reduction in feed intake. This reduction in feed intake is suggestive of the extent of the acceptance of Parkia hay to the goat. Thus, observations on the feed intakes suggest that these two feed ingredients complement each other at 25/75 and 50/50 ratios of mixture for an enhanced feeding value. However, the low nitrogen content $(4.05 \%)$ of the cassava peels is suggested to have limited the available ammonia to the rumen microbes thereby inhibiting feed intake, while

Table 2. Dry matter intake and nutrient digestibilities of cassava peels and Parkia filicoidea hay fed to the goat

\begin{tabular}{|c|c|c|c|c|c|c|c|}
\hline \multirow[t]{2}{*}{ Cassava: Parkia } & 1 & 2 & 3 & 4 & 5 & 6 & \multirow{2}{*}{$\begin{array}{l}\text { Standard } \\
\text { error }\end{array}$} \\
\hline & $100 / 0$ & $75 / 25$ & $50 / 50$ & $25 / 75$ & $0 / 100$ & Control & \\
\hline $\begin{array}{l}\text { Dry matter intake } \\
\text { (g/head per day) }\end{array}$ & $137^{\mathrm{a}}$ & $228^{\mathrm{c}}$ & $212^{\mathrm{d}}$ & $204^{c}$ & $153^{b}$ & $216^{d}$ & $4 \cdot 9$ \\
\hline $\begin{array}{l}\text { Digestible organic matter } \\
\text { intake }(\mathrm{g} / \text { day })\end{array}$ & $57 \cdot 1$ & $100 \cdot 9$ & $110 \cdot 4$ & 91 & 45.9 & $108 \cdot 2$ & $3 \cdot 2$ \\
\hline $\begin{array}{l}\text { Metabolizable energy } \\
(\mathrm{kJ} / \mathrm{kg} \mathrm{W} 0 \cdot 75 / \mathrm{d})^{b}\end{array}$ & $0 \cdot 21$ & $0 \cdot 41$ & $0 \cdot 41$ & $0 \cdot 34$ & $0 \cdot 17$ & $0 \cdot 40$ & - \\
\hline \multicolumn{8}{|l|}{$\begin{array}{l}\text { Apparent digestibilities of the } \\
\text { nutrients (\%) }\end{array}$} \\
\hline Dry matter & $58 \cdot 9^{c}$ & $58 \cdot 9^{c}$ & $60 \cdot 9^{d}$ & $52 \cdot 4^{b}$ & $44 \cdot 6^{\mathrm{a}}$ & $54.9^{\mathrm{bc}}$ & 2 \\
\hline Organic matter & $50 \cdot 9^{b}$ & $56 \cdot 9^{c}$ & $59 \cdot 5^{c}$ & $49 \cdot 4^{b}$ & $32 \cdot 2^{\mathrm{a}}$ & $55 \cdot 7^{\mathrm{c}}$ & $2 \cdot 5$ \\
\hline Crude protein & $15 \cdot 8^{\mathrm{a}}$ & $23 \cdot 3^{b}$ & $57 \cdot 0^{\mathrm{d}}$ & $56 \cdot 9^{d}$ & $56 \cdot 9^{\mathrm{a}}$ & $50 \cdot 2^{c}$ & $2 \cdot 5$ \\
\hline Crude fibre & $66 \cdot 5^{c}$ & $58 \cdot 1^{\mathrm{a}}$ & $61 \cdot 4^{b}$ & $60 \cdot 2^{a b}$ & $63 \cdot 0^{\mathrm{bc}}$ & $61 \cdot 1^{b}$ & 1.9 \\
\hline Ether extract & $81 \cdot 9^{c}$ & $62 \cdot 2^{b}$ & $80 \cdot 6^{c}$ & $62 \cdot 8^{b}$ & $45 \cdot 5^{\mathrm{a}}$ & $59 \cdot 1^{b}$ & $1 \cdot 8$ \\
\hline Nitrogen-free extract & $55 \cdot 7^{\mathrm{c}}$ & $30 \cdot 2^{\mathrm{a}}$ & $55 \cdot 7^{\mathrm{c}}$ & $46 \cdot 0^{\mathrm{b}}$ & $42 \cdot 1^{b}$ & $45 \cdot 6^{\mathrm{b}}$ & $2 \cdot 8$ \\
\hline Ash & $9 \cdot 1^{\mathrm{a}}$ & $36 \cdot 1^{b}$ & $66 \cdot 6^{c}$ & $75 \cdot 8^{d}$ & $88 \cdot 6^{\mathrm{e}}$ & $90 \cdot 3^{f}$ & $3 \cdot 0$ \\
\hline
\end{tabular}

a, b, c, Different superscripts indicate figures are statistically different $(P<0 \cdot 05)$.

${ }^{a}$ Calculated from mean value of digestible organic matter.

${ }^{b}$ Metabolizable energy calculated as $15 \cdot 6 \mathrm{~kJ} / \mathrm{kg}$ digestible organic matter (ARC, 1980). 
the poor intake of Parkia hay may have been due to digestibility. In both cases the supply of nitrogen would be marginal.

The digestibilities of dry matter were high on $100 / 0$, $25 / 75$ and $50 / 50$ mixtures. The observed values for the $25 / 75$ and 50/50 mixtures seem to reflect the nutritive values of the two diets. The cassava-peel diet is deemed to have been well digested on account of the low dry-matter intake and consequent attempt to maximize the use of the available nutrients. This is indicated by the somewhat high digestibilities of the fat, soluble carbohydrate, crude fibre, and thus the organic matter, over the corresponding values obtained for the Parkia hay $(0 / 100)$ diet. The $50 / 50$ cassava peel/Parkia hay combination had higher $(P<0.05)$ digestibility values in the nutrients considered, except for crude fibre and total ash (Table 2).

This factor could make the $50 / 50$ cassava peel/ Parkia hay combination the best of all the combinations in this study. The cost of supplemental concentrate in the control diet as against the little or no cost on the cassava or Parkia hay could make a combination of these plant products an acceptable feed for goats in periods of feed scarcity, especially in the dry season. On the other hand, these by-products can provide a suitably cheap general feed in subsistence, rural or sedentary goat production.

\section{ACKNOWLEDGEMENT}

This investigation was supported by the Senate Research grant, University of Ilorin, Nigeria for which the authors are grateful.

\section{REFERENCES}

Adeloye, A. (1992). Efficiencies of conversion of some lignocellulosic waste materials by goats. Biores. Technol., $\mathbf{4 0}$, 167-9.

AOAC (1980). Official Methods of Analysis (12th edn.). Association of Official Analytical Chemists, Washington, DC.

ARC (1980). The Nutrient Requirements of Ruminant Livestock. Agricultural Research Council, Commonwealth Agricultural Bureau, Farnham Royal, UK.

Balogun, A. M. \& Fetuga, B. L. (1986). Chemical composition of some under exploited leguminous crop seeds in Nigeria. J. Agric. \&Food Chem., 34, 189-92.

Balogun, O. O. \& Odutuga, A. A. (1982). Chemical composition and nutritive value of a lipid-protein concentrate from West African locust bean (Parkia filicoidea Welw.). Nutrition Reports International, 25, 867-78.

Duncan, D. B. (1955). Multiple range and multiple F-tests. Biometrics, 11, 1-42.

Fetuga, B. L., Babatunde, G. M. \& Oyenuga, V. A. (1974). Protein quality of some unusual protein foodstuffs: Studies on the African locust-bean seed (Parkia filicoidea Welw.). British J. Nutrition, 32, 27-36.

Ifut, O. J. (1983). Utilization of Gliricidia sepium and cassava peels by West African dwarf goats in Nigeria industry. Overcoming constraints to the efficient utilization of agricultural by-products as animal feed. In Proc. 4th Ann. Workshop, Institute of Animal Research. Mankon Station. Bamuda, Cameroon.

Minson. D. J. \& Milford, R. (1967). The voluntary intake and digestibility of diets containing different proportion of legume and mature pangola grass (Digitaria decumbens). Australian J. Experimental Agricultural and Animal Husbandry, 7, 546-51.

Oyenuga, V. A. (1968). Nigeria's Foods and Feedingstuffs (2nd edn.). Ibadan University Press, Ibadan.

Steel, R. G. D. \& Torrie, J. H. (1980). Principles and Procedures of Statistics. A Biometrical Approach (2nd edn.) McGraw-Hill, New York. 